\title{
RESENHA: Retratos do Brasil Homossexual: Fronteiras, Subjetividades e Desejos
}

\author{
Juliana Przybysz \\ Universidade Estadual de Ponta Grossa \\ juliana.przybysz@gmail.com
}

COSTA, Horácio et al. (Org.). Retratos do Brasil Homossexual: Fronteiras, Subjetividades e Desejos. São Paulo: Ed. Universidade de São Paulo: imprensa Oficial, 2010, 452 p.

O livro 'Retratos do Brasil Homossexual: Fronteiras, Subjetividades e Desejos' é resultado da seleção de trabalhos apresentados no IV Congresso da Associação Brasileira de Estudos da Homocultura (ABEH), ocorrido na Universidade de São Paulo (USP) no ano de 2008. Os organizadores: Horácio Costa, Berenice Bento, Wilton Garcia, Emerson Inácio e Wiliam Siqueira Peres foram responsáveis por compor cada uma das cinco partes da obra que reúnem textos sob as seguintes temáticas: Homocultura e Direitos Humanos, Homocultura e Literatura, Homocultura e Arte, Universo Trans e Pensar Identidades. Os organizadores da obra são oriundos das áreas de literatura, artes, ciências sociais e psicologia, compondo campos de saber complementar e, mutuamente, enriquecedores que influenciaram na composição do livro em tela.

A produção do livro, composto por trinta e cinco artigos organizados em cinco partes, reflete não apenas o avanço conceitual e metodológico dos estudos homossexuais, mas também o fortalecimento de uma luta política que se aprofunda no campo científico, desenvolvido na prática dos pesquisadores e das universidades. Costa (2010, p. 15), alerta que: "só pode ser feliz no sentido moderno da palavra quem tem suas identidades e suas particularidades respeitadas pelo Estado e pelo espaço social cotidiano", comprometendo o pensamento científico com a conquista de direitos sociais por parte da parcela da sociedade que, pelas vivências homossexuais, tem tido seu direito à felicidade constantemente negada.

A primeira parte da obra envolve o tema a 'Homocultura e Direitos Humanos', trazendo discussões sobre casamento, constituição de famílias e os avanços e limites presentes na sociedade brasileira e espanhola. A família, defendem os autores, deve ser constituída a partir dos sentimentos e não restrita à reprodução. O casamento é uma instituição social e não 'natural' e, sendo assim, em função da igualdade de direitos conquistada na Constituição Brasileira de 1988, é necessário o reconhecimento do casamento entre pessoas do mesmo sexo. A análise da sociedade espanhola, também é abordada nessa parte do livro, que evidencia os avanços de direitos homossexuais, como a regularização do matrimônio e a paternidade/maternidade de casais homossexuais, mas que até os dias atuais, convive com preconceitos. Outro importante elemento, que compõe essa parte do livro, é a necessidade de expandir a análise científica e acadêmica sobre gênero e sexualidades, evidenciando que isso também é uma atitude política, podendo ampliar o debate em torno de direitos sociais homossexuais.

Os nove textos que compõem a segunda parte, intitulada 'Homocultura e Literatura', possuem abordagens plurais, trazendo desde a emergência do homoerotismo na literatura e crítica literária, até a análise de obras literárias específicas em que personagens e dramas homossexuais são retratados e ganham expressão. A literatura constitui um campo discursivo em que elementos de poder e subversão podem ser interpretados socialmente. Assim, a evidência homoerótica, longe de ser considerada como um tema literário de menor valor deve ser visto como uma possibilidade de expressão, dentre as muitas outras formas de manifestação linguística artística.

Assim como na literatura, o homoerotismo compõe as artes retratadas na terceira parte do livro: 'Homocultura e Artes'. Os autores dos seis trabalhos, reunidos nesta parte, evidenciam a homossexualidade meios de comunicação artística impressos que englobam fotos, colagens, pinturas, entre outros, bem como, peças de teatro e produção fílmica. A forma artística que ganhou visibilidade no livro foi o museu travesti, presente no Peru que é tratado no livro como uma visão multifocal do travestismo neste país. É, neste mesmo movimento de visibilidade, que o cinema é abordado a partir das subjetividades homoafetivas, trazendo as experiências, vivências de desejos, e lutas pela afirmação de identidades homossexuais. A homocultura desenvolvida por meio do teatro resgata a abordagem do gay como um ser cômico até a 
modernidade que demonstra temas ligados a homofobia. As múltiplas facetas da subjetividade são exploradas também por meio das representações fotográficas em que corpos e marcas publicitárias criam e recriam desejos e identidades.

A quarta parte do livro, sob o título: 'Universo trans' é composta por três textos que exploram a existência travesti em diversos contextos urbanos no Brasil. Os autores trazem os elementos que constroem estigmas, os quais dificultam a vivência cidadã das pessoas que transgridem as normas de gênero de forma tão evidente, como as travestis. Suas dificuldades de existência são abordadas em distintas facetas, envolvendo a rejeição da família, da comunidade escolar e notadamente a negligência social com a saúde das travestis e de suas estratégias solitárias para alcançar o gênero desejado e as consequências advindas ao uso indiscriminado de silicone industrial e hormônios femininos.

A última parte do livro: 'Pensar Identidades', apresenta uma ampla diversidade de elementos abordados em dez textos. As diversas formas de construção das masculinidades e a abolição da ideia de um único modelo padrão masculino é alvo de discussão do livro. O texto evidencia o modelo hegemônico que associa corpos biológicos ao gênero e desejo, trazendo a ideia da necessidade de nossa sociedade contemplar as diversas possibilidades de masculinidades, bem como de feminilidades. As relações de poder nas práticas de militância política de direitos cidadãos são evidenciadas na abordagem de vivências de grupos de gays e de lésbicas, trazendo elementos de machismo e misoginia presentes na ação política. As sociabilidades de lésbicas no Rio de Janeiro, dos anos 60, também é tema do livro que discute locais de encontros e códigos de reconhecimento de mulheres que amam outras mulheres. Estes lugares transgressores da heteronormatividade ganham visibilidade por meio do resgate de vivências possíveis que a história oficial negligenciou.

A interseccionalidade de sujeitos transpassados pela homossexualidade, raça e masculinidades compõe esta última parte do livro que evidencia a discriminação e os conflitos gerados em diferentes espaços na existência de sujeitos negros, gays na cidade de Goiânia. Outra forma de discriminação é tratada nesta parte do livro, envolvendo práticas invisíveis em um estudo de caso retratado por um casal homoafetivo espanhol, o qual tentava a adoção de uma criança brasileira. As formas de discriminação vieram como verdades proferidas pelos peritos na área de psicologia e assistência social, que fazem parte do processo judicial e baseiam as sentenças dos juízes.
As diversas masculinidades gays é tema de exame no texto que aborda os elementos publicitados nos perfis de sites de relacionamentos gays, evidenciando uma pluralidade de possibilidades e vivências gays e desconstruindo a ideia de homogeneidade do universo homossexual masculino. Outro elemento de sociabilidade de grupos de gays e bissexuais é o uso das chamadas 'Club drugs' que se constituem em substâncias químicas, os quais facilitam os contatos e os relacionamentos pelos resultados de euforia que provocam. Contudo, o uso de substâncias também prejudicam os cuidados com a vulnerabilidade ao HIV dos grupos de usuários. Outra abordagem, desta parte do livro, é o discurso da imprensa nacional na construção das identidades de gays e como instrumento de luta contra a discriminação. A identidade também recebeu atenção, neste livro, no que diz respeito ao ambiente escolar, envolvendo atores como professores e alunos que vivenciam cotidianamente a escola que constitui um importante local de construção de identidades. Além da escola, a igreja católica é referente de análise das identidades homossexuais que aborda a pluralidade de abordagens possíveis em torno do discurso religioso da homossexualidade, evidenciando que o discurso católico não é monolítico havendo outras possibilidades contra hegemônicas de interpretação das vivências homossexuais.

O livro 'Retratos do Brasil Homossexual: Fronteiras, Subjetividades e Desejos' além de apresentar uma pluralidade de abordagens da realidade vivida por diferentes grupos da comunidade LGBTT, se constitui em um marco de luta científica e política que deve ser incorporado nas mais variados campos das ciências sociais e de ponto de apoio para a construção de uma sociedade igualitária do ponto de vista de direitos humanos, mas plural, capaz de incorporar a diversidade da experiência humana.
Recebido em 02 de março de 2010. Aceito em 14 de abril de 2011.

Juliana Przybysz 